\title{
Determination of Yield and Botanical Composition of the Meadow and Grassland in Çolpan Village at the Shores of Lake Van
}

\author{
Mehmet Macit Ertuş 1,a,* \\ ${ }^{I}$ Department of Plant and Animal Production, Çölemerik Vocational School, Hakkari University, 30000 Hakkari, Turkey \\ *Corresponding author

A R T I C L E INFO A B S T R A C T \\ Research Article \\ This study was carried out at the meadows and pastures in Çolpan village of Van province in 2020. \\ In the study, matter yield, botanical composition, plant covered area, rate of \\ decreaser/increaser/invader species were determined. The Loop method was used to determine the \\ botanical composition. In grassland area were identified 69 species belonging to 17 families. In \\ meadow area were identified 20 species belonging to 6 families. The amount of Poaceae, Fabaceae \\ and other families found in the grassland area were determined as $18.66 \%, 15.65 \%$, and $65.69 \%$, \\ respectively. In the meadow area, the amount of Poaceae, Fabaceae and other families were \\ determined as $67.50 \%, 15.0 \%$, and $17.50 \%$, respectively. Artemisia spicigera $(4.74 \%)$ \\ Taeniatherum caput-medusae (5.0\%) Arenaria serpyllifolia (5.0\%) Medicago monantha (5.92\%) \\ species were the most common species found in the grassland area. Hordeum brevisubulatum \\ (25.5\%), Bromus scoparius (16.75\%), and Taraxacum androssovii $(9.25 \%)$ species were the most \\ common species found in the meadow area. According to the ratio of good plants, pasture was \\ classified as poor pasture and meadow was in the moderate meadow class. Grassland and meadow \\ matter yields were found to be $91.4 \mathrm{~kg} / \mathrm{da}$ and $385.2 \mathrm{~kg} / \mathrm{da}$, respectively. In the grassland of Colpan \\ village, invader species were found to be dense. It was concluded that grassland area should be \\ improved.

\begin{tabular}{|c|c|}
\hline $\begin{array}{l}\text { Keywords: } \\
\text { Grassland } \\
\text { Van } \\
\text { Meadow } \\
\text { Botanical composition } \\
\text { Yield }\end{array}$ & $\begin{array}{l}\text { species were the most common species found in the grassland area. Hordeum brevisubulatum } \\
(25.5 \%) \text {, Bromus scoparius }(16.75 \%) \text {, and Taraxacum androssovii }(9.25 \%) \text { species were the most } \\
\text { common species found in the meadow area. According to the ratio of good plants, pasture was } \\
\text { classified as poor pasture and meadow was in the moderate meadow class. Grassland and meadow } \\
\text { matter yields were found to be } 91.4 \mathrm{~kg} / \mathrm{da} \text { and } 385.2 \mathrm{~kg} / \mathrm{da} \text {, respectively. In the grassland of Çolpan } \\
\text { village, invader species were found to be dense. It was concluded that grassland area should be } \\
\text { improved. }\end{array}$ \\
\hline
\end{tabular}

\section{Introduction}

Quality roughage shortage is still one of the most important problem of animal husbandry of Turkey (Sayar et al., 2010; Başbag et al., 2015). Meadows and grasslands are the cheapest source of quality roughage because they do not require any planting or care in general and they contain cheap and various types of plants (Bakır, 1987; Açıkgöz, 2001). There are 14.6 million hectares of grassland and 1.45 million hectares of meadow in Turkey (Topçu Demiroğlu and Özkan, 2017). Although the total dry matter produced and the feed quality of these meadows is always lower than the conventional feed crops obtained from monoculture or grass-legume mixtures (Tallowin and Jefferson, 1999; Sturludóttir et al., 2013), these offer benefits to overcome future agricultural challenges that go beyond the animal performance level (Hammond et al, 2014; Reiné et al., 2020). In the Eastern Anatolian Region, grasslands are grazed with animals from spring to autumn, while meadows are usually mown once in July and after mowing, they are grazed with animals, and these generally wet areas are compacted by animals (Manga, 1975). Most of the grasslands are located in arid and semi-arid climatic zones. Van province has 1.239.289 ha of grassland area and 119.733 ha of meadow area (Turan and Altuner, 2014). Failure to comply with management rules of low rainfall is one of the most important reasons for the degradation of vegetation in grasslands (Holechek et al., 2004).

Grazing pressure on meadows and grasslands, which are an indispensable element of economic animal husbandry, is increaser in parallel with the needs of the increaser population. This pressure on grasslands and early grazing brought about a decrease in yield (Sayar et al., 2015). However, the increaser need for shelter of the increaser population is also destroyed by the new roads and agricultural areas built. Grasslands are natural resources that can be used for a long time and renew themselves if grassland management rules are abided. However, if these rules are not abided, they turn into inefficient and barren fields in a very short time (Bilgen and Özyiğit, 2005). Our country's grasslands are in a position to negatively affect our livestock breeding, and therefore the country's 
economy (Çınar et al., 2014). The quality of the grassland decreases as a result of the decrease in good breed plants in the grasslands under heavy grazing pressure and the settlement of animal species that do not graze. As the excessive and irregular use of grassland continues, harmful plant species with low quality and weed characteristics settle over time instead of the climax plant species in the vegetation. Some of the invader species that are described as weed cause injuries with their thorns, and some of them adversely affect the quality and quantity of animal products with the toxic substances they contain and sometimes cause animal deaths (Balabanl et al., 2006). Studies have reported that good-breed plants decrease in vegetation due to the pressure on the grasslands and invader species increase (Koç and Gökkuş, 1994; Çınar et al., 2014; Sayar et al., 2015). Grasslands, which are of great importance in terms of natural balance, have lost their productivity to a large extent due to the effect of grazing in the early or late periods above their capacity (Çomaklı et al., 2012). The botanical composition must be known in order for grassland improvement or management studies to be planned and to succeed (Babalık and Kılıç, 2015; Seydoşoğlu et al., 2015). This study was conducted in order to determine the botanical composition of the meadows and grasslands in Çolpan village at the shore of Lake Van.

\section{Materials and Methods}

The study was carried out in meadows and grasslands in Çolpan village in the vegetation period of 2020, within the borders of Tuşba district of Van province. The grassland area of Çolpan village is $5.482 \mathrm{da}$, the fodder plantation area is $1.175 \mathrm{da}$, the number of sheep and goats is 152, and the number of bovine animals is 525 (Anonymous, 2017). Located by Lake Van, the village is 1.716 meters above sea level. The study area consists of 12 ha of meadow and 82 ha of grassland area located near the settlement of the village (Figure 1,2,3). In the other grassland area of Çolpan village, the study could not be carried out as it was not possible to identify plants in grassland under heavy grazing pressure. The meadow where the study was conducted is a natural meadow, which is mown, and grazed after mowing.

The amount of precipitation in the province of Van for the year 2020 was recorded as $377.3 \mathrm{~mm}$, which is close to the long-term average $(387.9 \mathrm{~mm})$. The average temperature and relative humidity for the long term are $9.18^{\circ} \mathrm{C}$ and $57.93 \%$, and $9.32^{\circ} \mathrm{C}$ and $55.84 \%$ for 2020 . It receives the most rainfall in March, April, and May (Anonymous, 2020).

The area covered with plants, botanical composition, forage yield and condition of grassland and meadow were investigated in this study. The Loop method was used to determine the botanical composition. For this reason, 4 Loop direction were conducted in the grassland area and 2 Loop direction in the meadow area. Size of each direction consisted of 100 measurements. Measurements were made in each direction at every other $20 \mathrm{~cm}$ on a $20 \mathrm{~m}$ line extending in 4 directions from a point considered as the center of each Loop. In total, 400 measurements were made in each Loop. The dominant species in the measurement was recorded, the number of species found in each loop was divided by the number of measurements, and the ratio of the plant covered area was obtained. The ratio of the species in the composition was calculated over the area covered with plants. In identifying the plant species encountered in the vegetation's greatly benefited from Davis (1978) and Serin et al. (2008). The decreaser, increaser, and invader species, which express the plant species' palatability and their responses to grazing, have been defined by "Turkey's Meadow and Grassland Plants" (Serin et al., 2008). In order to determine the herbage yield, samples were taken from the area within a $50 \times 50 \mathrm{~cm}$ frame from 6 points representing the meadow and grassland. The samples were dried in a drying cabinet at $70^{\circ} \mathrm{C}$ for 48 hours and the rate of dry matter was calculated.

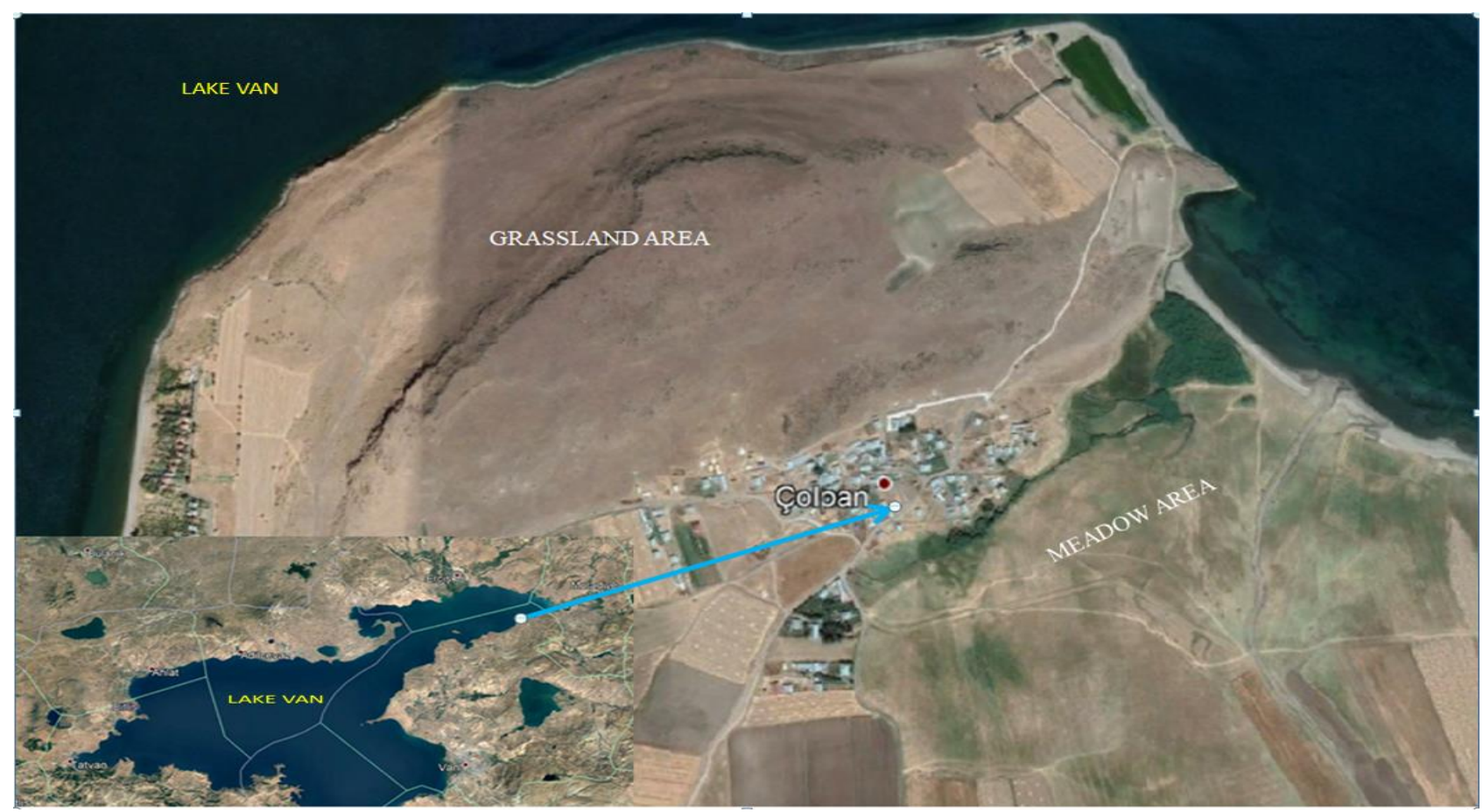

Figure 1. Place of study area (Google earth) 

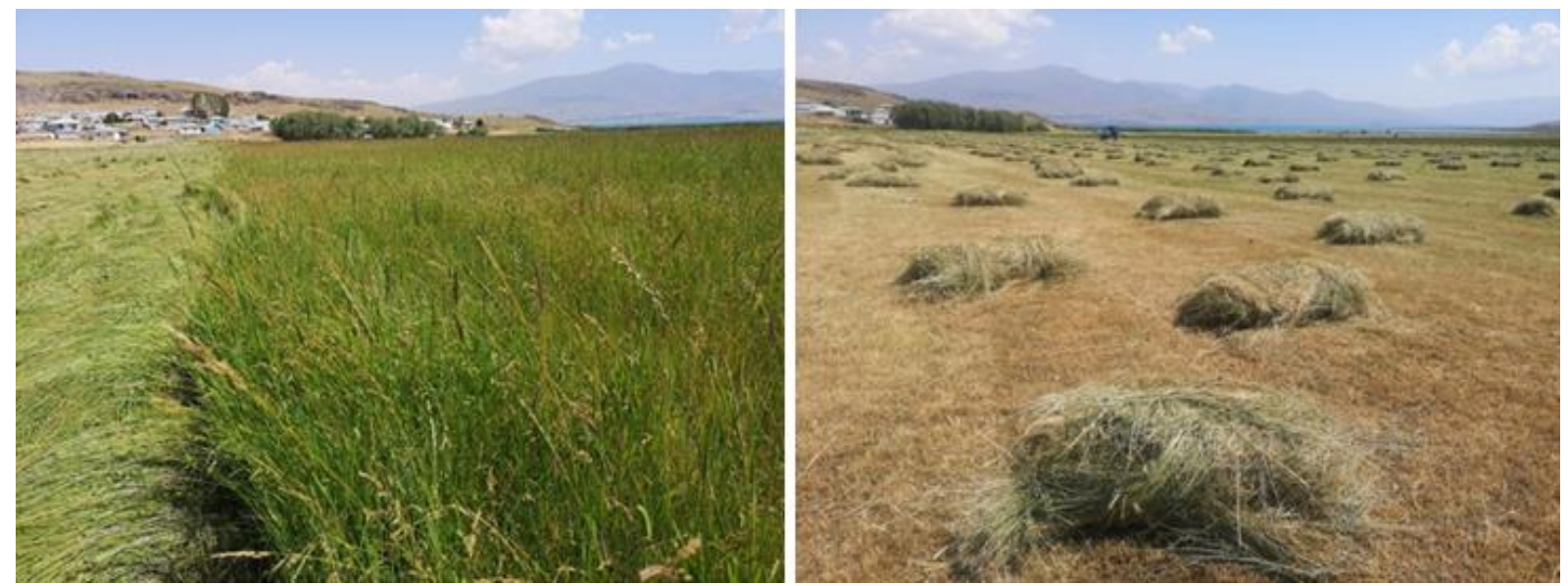

Figure 2. Images from the meadow area
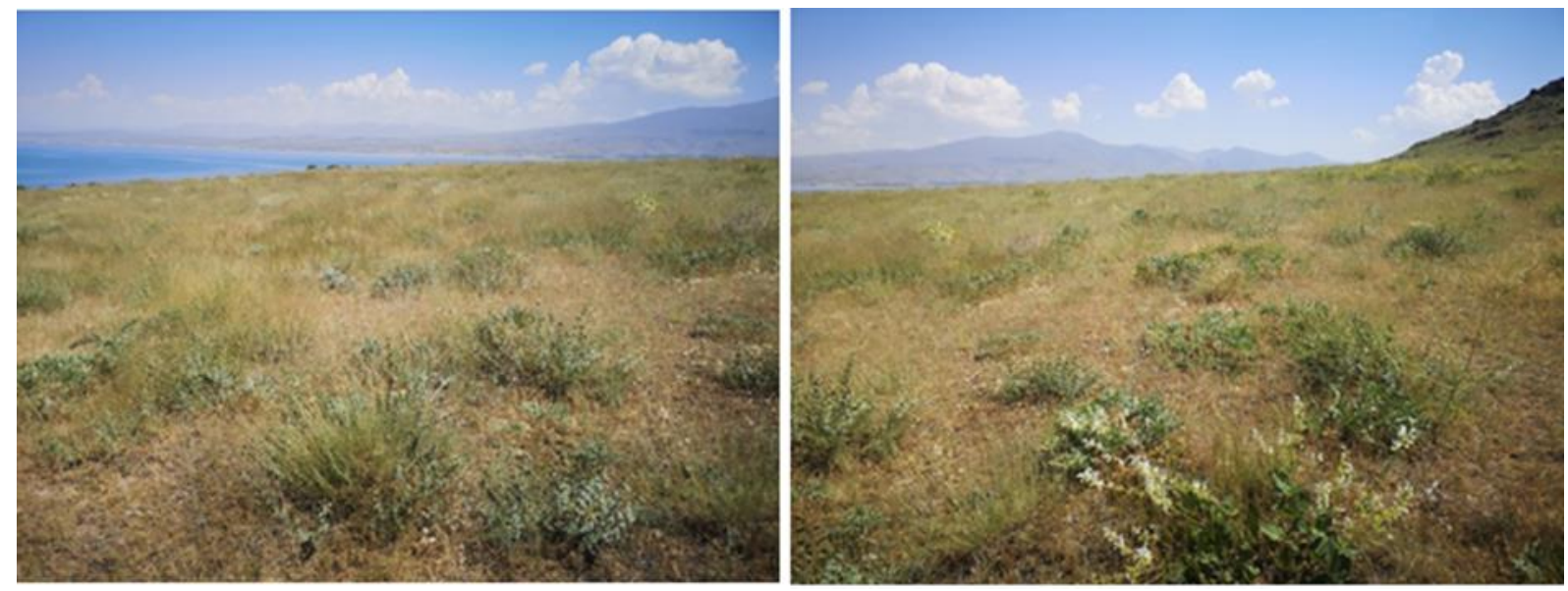

Figure 3. Images from the grassland area

\section{Results and Discussion}

\section{Area Covered with Plant}

The study results revealed that the meadow area was covered with plants $100 \%$. The area covered with vegetation in the examined part of the grassland of Çolpan village was determined as 86\%. Çınar et al. (2014), reported that the area covered with plants in five different grasslands is between 84.4-99.0\%, and in a different study, Çınar et al. (2014) reported that the average rate was 95.3\%. Çaçan and Başbağ (2016) reported that the area covered with plants is an average of $68.19 \%$, and it varies between $48.25-86.67 \%$ according to years, directions, and altitudes.

Ünal et al. (2012) reported that the area covered with plants may differ according to the use of grassland, and also different results may be obtained with the effect of grazing pressure and vegetation measurement methods.

\section{Botanical Composition}

Poaceae, Astereceae, and Fabaceae families had the highest density in the grassland area and Cuscutaceae, Dipsacaceae, and Hypericaceae had the the lowest. Similarly; many researchers reported that Fabaceae, Asteraceae, and Poaceae families were more found in natural meadow and grasslands of the Turkey than other plant families (Beyiş and Sabanc1, 2011; Çaçan et al. 2014; Babalık and Sarıkaya, 2015; Şahin et al. 2015; Çınar et al., 2018; Çınar et al., 2019).
In the grassland area were identified 69 species belonging to 17 families. Total of 37 species in the grassland were perennial $(45.29 \%)$, two are annual, biennial, or perennial $(0.26 \%), 27$ were annual $(47.61 \%)$, and 3 were biennial $(6.84 \%)$. (Table 1, Figure 4$)$. It has been reported that perennial species were more common in different grasslands of our country (Çınar et al. 2019; Ertuş and Pinar, 2019). Aydin et al. (2014) reported that the annual species were more common in the grassland area. Artemisia spicigera (4.74\%) Taeniatherum caput-medusae (5.0\%) Arenaria serpyllifolia (5.0\%) Medicago monantha $(5.92 \%)$ species were the most common species found in the grassland area.

In the meadow area were identified 21 species belonging to 6 families. Total of 6 species in the meadow were identified as annual (20.75\%), 1 as biennial (1.0\%), 12 as perennial (76.50\%), 1 as annual or biennial (1.75\%). In the area where Poaceae family $(67.50 \%)$ is very dense, species from Fabaceae and Asteraceae families have also been seen in a significant proportion. On the basis of species, the most frequent were Hordeum brevisubulatum (25.5\%), Bromus scoparius (16.75\%), Taraxacum androssovii $(9.25 \%)$ and at least frequent were Achillea millefolium (1\%), Medicago rigidula (1.0\%), Silene conica (1\%) (Table 2, Figure 4). In meadow vegetation, as in grassland vegetation, the rate of perennial species were found to be higher. 
Table 1. Botanical Composition and Some Features of Çolpan Village Grassland

\begin{tabular}{|c|c|c|c|c|c|c|}
\hline Family & Genus-Species & DEC & INC & INV & $\mathrm{PPC}$ & Form* \\
\hline \multirow{4}{*}{ Apiaceae } & Eryngium billardierei & & & + & 1.32 & $\mathrm{P}$ \\
\hline & Grammosciadium daucoides & & & + & 0.92 & $\mathrm{P}$ \\
\hline & Pimpinella tragium & & & + & 0.79 & $\mathrm{P}$ \\
\hline & Prangos ferulacea & & & + & 1.05 & $\mathrm{P}$ \\
\hline \multirow{10}{*}{ Asteraceae } & Achillea arabica & & & + & 0.67 & $\mathrm{P}$ \\
\hline & Artemisia spicigera & & & + & 4.74 & $\mathrm{P}$ \\
\hline & Cnicus benedictus & & & + & 0.26 & A \\
\hline & Cota wiedemanniana & & & + & 2.50 & A \\
\hline & Cousinia urumiensis & & & + & 2.11 & $\mathrm{P}$ \\
\hline & Cymbolaena griffithii & & & + & 0.79 & A \\
\hline & Lactuca scarioloides & & & + & 0.26 & $\mathrm{~B}$ \\
\hline & Senecio vernalis & & & + & 1.84 & A \\
\hline & Tanacetum polycephalum & & & + & 0.92 & $\mathrm{P}$ \\
\hline & Xeranthemum аппиит & & & + & 1.84 & A \\
\hline \multirow{4}{*}{ Boraginaceae } & Alkanna orientalis & & & + & 0.79 & $\mathrm{P}$ \\
\hline & Onosma isaurica & & & + & 0.26 & $\mathrm{P}$ \\
\hline & Rindera lanata & & & + & 1.18 & $\mathrm{P}$ \\
\hline & Rochelia disperma & & & + & 0.13 & A \\
\hline \multirow{5}{*}{ Brassicaceae } & Alyssum desertorum & & & + & 1.97 & $\mathrm{~A}$ \\
\hline & Alyssum szovitsianum & & & + & 2.89 & A \\
\hline & Lepidium draba & & & + & 0.67 & $\mathrm{P}$ \\
\hline & Erysimum uncinatifolium & & & + & 3.82 & $\mathrm{~B}$ \\
\hline & Sisymbrium altissimum & & & + & 0.39 & A \\
\hline \multirow{6}{*}{ Caryophyllaceae } & Arenaria blepharophylla & & + & & 2.37 & $\mathrm{P}$ \\
\hline & Arenaria serpyllifolia & & & + & 5.00 & $\mathrm{~A}$ \\
\hline & Dianthus orientalis & & & + & 0.26 & $\mathrm{P}$ \\
\hline & Gypsophila ruscifolia & & + & & 0.67 & $\mathrm{P}$ \\
\hline & Silene argentea & & & + & 0.79 & $\mathrm{P}$ \\
\hline & Velezia rigida & & & + & 0.79 & A \\
\hline \multirow{2}{*}{ Chenopodiaceae } & Bassia prostrata & & & + & 0.53 & $\mathrm{P}$ \\
\hline & Salsola boissieri & & & + & 0.39 & A \\
\hline Cistaceae & Helianthemum ledifolium & & & + & 4.34 & $\mathrm{~A}$ \\
\hline Cuscutaceae & Cuscuta approximata & & & + & 0.13 & $A \& P$ \\
\hline Cyperaceae & Carex stenophylla & & & + & 2.24 & $\mathrm{P}$ \\
\hline Dipsacaceae & Scabiosa argentea $\mathrm{L}$. & & & + & 0.13 & $\mathrm{~B} \& \mathrm{P}$ \\
\hline \multirow{2}{*}{ Euphorbiaceae } & Euphorbia heteradena & & & + & 0.67 & $\mathrm{P}$ \\
\hline & Euphorbia esula & & & + & 0.53 & $\mathrm{P}$ \\
\hline \multirow{7}{*}{ Fabaceae } & Astragalus aduncus & & & + & 0.13 & $\mathrm{P}$ \\
\hline & Astragalus cancellatus & & & + & 2.89 & $\mathrm{P}$ \\
\hline & Medicago monantha & & & + & 5.92 & A \\
\hline & Medicago rigidula & & & + & 3.95 & $\mathrm{~A}$ \\
\hline & Medicago sativa & + & & & 1.18 & $\mathrm{P}$ \\
\hline & Trifolium arvense & & & + & 0.79 & A \\
\hline & Trifolium hirtum & & & + & 0.79 & A \\
\hline Geraniaceae & Erodium cicutarium & & & + & 1.45 & $\mathrm{~A}$ \\
\hline Hypericaceae & Hypericum scabrum & & & + & 0.39 & $\mathrm{P}$ \\
\hline \multirow{8}{*}{ Lamiaceae } & Clinopodium graveolens & & & + & 1.05 & $\mathrm{~A}$ \\
\hline & Salvia frigida & & & + & 1.05 & $\mathrm{P}$ \\
\hline & Salvia multicaulis & & & + & 1.45 & $\mathrm{P}$ \\
\hline & Salvia syriaca & & & + & 0.26 & $\mathrm{P}$ \\
\hline & Sideritis montana & & & + & 0.39 & $\mathrm{~A}$ \\
\hline & Teucrium chamaedrys & & & + & 0.26 & $\mathrm{P}$ \\
\hline & Teucrium polium & & + & & 0.92 & $\mathrm{P}$ \\
\hline & Thymus kotschyanus & & & + & 2.50 & $\mathrm{P}$ \\
\hline Plumbaginaceae & Acantholimon caryophyllaceum & & & + & 2.24 & $\mathrm{P}$ \\
\hline \multirow{13}{*}{ Poaceae } & Bromus danthoniae & & & + & 0.92 & $\mathrm{~A}$ \\
\hline & Bromus erectus & + & & & 0.26 & $\mathrm{P}$ \\
\hline & Bromus japonicus & & & + & 0.26 & A \\
\hline & Bromus tectorum & & & + & 1.97 & $\mathrm{~A}$ \\
\hline & Dactylis glomerata & + & & & 1.05 & $\mathrm{P}$ \\
\hline & Elymus hispidus & + & & & 1.18 & $\mathrm{P}$ \\
\hline & Eremopoa persica & & & + & 1.18 & $\mathrm{~A}$ \\
\hline & Gaudiniopsis macra & & & + & 0.26 & A \\
\hline & Hordeum marinum & & & + & 0.53 & A \\
\hline & Koeleria cristata & + & & & 1.18 & $\mathrm{P}$ \\
\hline & Poa bulbosa & & + & & 4.08 & $\mathrm{P}$ \\
\hline & Stipa holosericea & & + & & 0.79 & $\mathrm{P}$ \\
\hline & Taeniatherum caput-medusae & & & + & 5.00 & A \\
\hline Santalaceae & Thesium billardieri & & & + & 2.76 & $\mathrm{~B}$ \\
\hline Total & & & & & 100 & \\
\hline
\end{tabular}




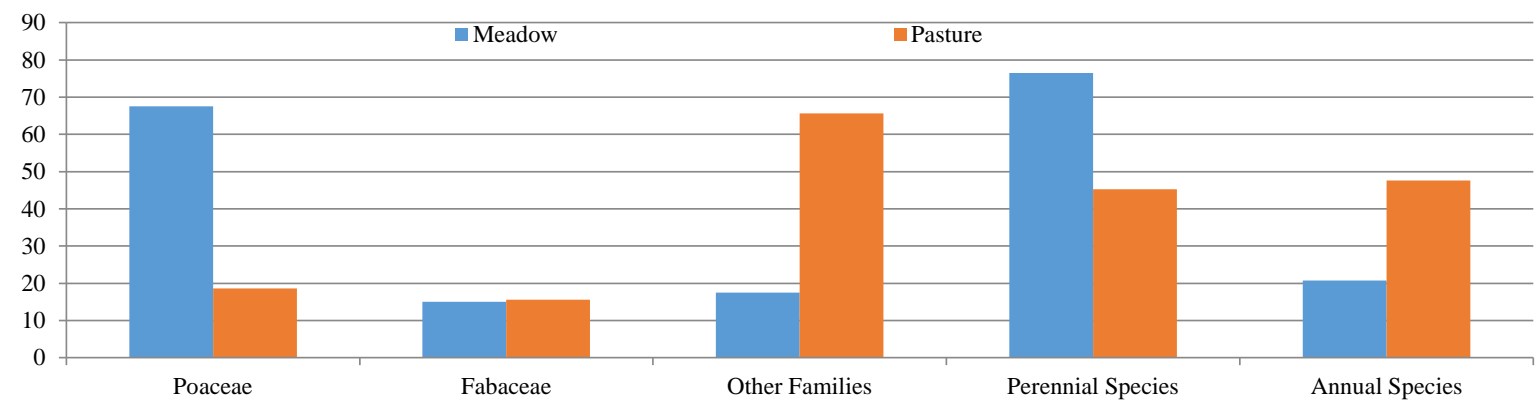

Figure 4. Botanical composition of meadow and grassland (\%)

Table 2. Botanical Composition and Some Features of Çolpan Village Meadow Area

\begin{tabular}{|c|c|c|c|c|c|c|}
\hline Family & Genus-Species & $\overline{D E C}$ & INC & INV & PPC & Form* \\
\hline \multirow{4}{*}{ Asteraceae } & Achillea millefolium & & & + & 2.00 & $\mathrm{P}$ \\
\hline & Scorzonera cana & & & + & 1.25 & $\mathrm{P}$ \\
\hline & Taraxacum androssovii & & & + & 9.25 & $\mathrm{P}$ \\
\hline & Tragopogon porrifolius & & & + & 1.00 & B \\
\hline \multirow{2}{*}{$\begin{array}{l}\text { Caryophyllaceae } \\
\text { Cyperaceae }\end{array}$} & Silene conica & & & + & 1.00 & A \\
\hline & Carex melanostachya & & & + & 3.00 & $\mathrm{P}$ \\
\hline \multirow{7}{*}{ Fabaceae } & Lotus corniculatus & + & & & 4.50 & $\mathrm{P}$ \\
\hline & Medicago lupulina & & + & & 1.00 & $\mathrm{P}$ \\
\hline & Medicago rigidula & & & + & 1.00 & A \\
\hline & Medicago varia & + & & & 1.75 & $\mathrm{P}$ \\
\hline & Trifolium ambiguum & + & & & 2.50 & $\mathrm{P}$ \\
\hline & Trifolium resupinatum & & & + & 2.50 & A \\
\hline & Vicia villosa & & & + & 1.75 & $\mathrm{~A} \& \mathrm{~B}$ \\
\hline \multirow{7}{*}{ Poaceae } & Bromus scoparius & & & + & 16.25 & A \\
\hline & Elymus hispidus & + & & & 1.75 & $\mathrm{P}$ \\
\hline & Hordeum brevisubulatum & & + & & 25.5 & $\mathrm{P}$ \\
\hline & Lolium perenne & & & + & 13.5 & $\mathrm{P}$ \\
\hline & Phalaris aquatica & + & & & 3.75 & $\mathrm{P}$ \\
\hline & Poa bulbosa & & + & & 3.00 & $\mathrm{P}$ \\
\hline & Poa langifolia & + & & & 2.00 & $\mathrm{P}$ \\
\hline Ranunculaceae & Ranunculus damascenus & & & + & 1.75 & $\mathrm{P}$ \\
\hline Total & & & & & 100.0 & \\
\hline
\end{tabular}

*A: Annual, B: Biennial, P: Perennial, DEC: Decreaser, INC: Increaser, INV: Invader, PPC: Percentage of Plant Coverage

Forage Yield and Condition of Meadow and Grassland

Dry matter yield in the grassland area was found to be between $68.73-106.9 \mathrm{~kg} / \mathrm{da}$ and $91.40 \mathrm{~kg} / \mathrm{da}$ on average. This is compatible with the findings of Ertuş et al. (2018), which were higher than the findings of Buzuk et al. (2009) and Çiplak (2015) working at the grasslands in Van. The dry matter yield of the meadow area was found to be between $331.6-452.9 \mathrm{~kg} / \mathrm{da}$ and $385.2 \mathrm{~kg} / \mathrm{da}$ on average. The dry matter yield in the meadows of the Kars region was reported to be between 196.0-250.0 kg/da (Arslan and Tufan, 2011),

The coverage rate of grasses, legumes, and other families of plants in the grassland area were found to be $18.66 \%, 15.65 \%$, and $65.69 \%$ respectively. Çaçan et al. (2014) found the ratio of plants from other families (43.14\%) in Bingöl grasslands higher than the ratios of grasses $(29.77 \%)$ and legumes $(27.08 \%)$, which were close to each other. Altin et al. (2010) reported that in the barren grassland area of Tekirdağ, grasses take more place in the botanical composition. Terzioğlu and Yalvaç (2004), in the Atmaca and Döneç villages in Van and Bakoğlu and Koç (2002) in Erzurum conditions reported that the proportion of grasses is higher than that of legumes and other families. On the grassland of Onağıl village in Van, Ertuş et al. (2018) reported that the rate of grasses is $45.37 \%$, legume is $9.97 \%$, and other family species is $44.66 \%$. Bakoğlu et al. (2019), working at Handüzü plateau in Rize, reported that it consists of $33.37 \%$ grasses, $5.75 \%$ legumes, and $60.88 \%$ plants from other families. Findings were generally compatible with Çaçan et al. (2014). It is not compatible with other studies, the grazing pressure on the grassland, grassland management style such as grazing animal species and the fact that the research areas have ecologies cause decrease in some plant species in vegetation or the spread of some species.

The ratio of grasses, legumes, and other families in the meadow area was found to be $62.75 \%, 19.0 \%$, and $18.25 \%$, respectively. Temel et al. (2016), in their study on arid meadows with different soil characteristics, found that other family species were more dense than grasses. The difference in the findings is due to the different ecologies of the study areas.

In the botanical composition of the grassland area, the decreaser, increaser, and invader species were found to be $4.85 \%, 8.69 \%$, and $86.46 \%$, respectively. In the grassland, the prominent decreaser species were found to be Medicago sativa, Elymus hispidus, Koeleria cristata with $1.18 \%$, the increaser were Poa bulbosa (\%4.08) and Arenaria blepharophylla (\%2.37), and the invader were Medicago monantha (\%5.92), Arenaria serpyllifolia 
(\%5.00), Taeniatherum caput-medusae (\%5.00) and Artemisia spicigera (\%4.74). In terms of decreaser/increaser/invader plant species, it has great similarities to Ünal et al. (2012) and Ertuş et al. (2018). In the meadow area, on the other hand, the rate of decreaser, increaser, and invader species were found to be $16.25 \%$, $29.5 \%$, and $54.25 \%$, respectively.

It has been found that the rate of good species plants in meadow is moderate and in grassland areas is low. According to the ratio of good plants, pasture was classified as poor pasture and meadow was as moderate meadow class. In our country's grasslands, invader plant species are also reported to be more than good genus plant species by Koç and Gökkuş (1994), Buzuk et al. (2009), Beyiş and Sabancı (2011), Aydın et al. (2014), Çınar et al. (2014), Seydoşoğlu et al. (2015), İspirli et al. (2016), Palta and Genç Lermi (2018) and Ertuş and Pınar (2019).

\section{Conclusion}

The species in the meadows and grasslands in Çolpan village at the shores of Van Lake were attempted to be identified and the state of the meadows and grasslands were attempted to be determined by taking decreaser, increaser, and invader species and the yield. The dry matter yield of the grassland was found to be $91.40 \mathrm{~kg} / \mathrm{da}$ and the dry matter yield of the meadow area to be $385.2 \mathrm{~kg} / \mathrm{da}$. The ratio of grasses was seen to be $62.75 \%$ and $18.66 \%$ in meadows and grasslands, respectively. It has been found that the ratio of good breed plants in grassland is in the weak grassland class with $13.67 \%$. In the meadow area, there were $45.75 \%$ good genus plant species. It was determined that the pasture was in the weak class and the meadow was in the moderate class. Meadows are mainly harvested. However, it should be taken into account that good genus species will be exposed to more grazing pressure as they are grazed with animals after the harvest. Therefore, it is important to avoid heavy grazing in the meadow area. As for the grassland area, improvement activities are recommended.

\section{References}

Açıkgöz E. 2001. Forage Crops. Uludag University Faculty of Agriculture Publications, No:182, Bursa, pp. 575.

Altın M, Tuna C, Gür M. 2010. Effects of Fertilizer Application on Forage Production and Botanical Composition of Floodplain and Steppe Rangelands of Tekirdağ. Journal of Tekirdag Agricultural Faculty. 7 (2).191-198

Anonymous 2020. Republic of Turkey Ministry of Forest and Water Affairs. General Directorate of Meteorology Van Meteorology Station Records.

Anonymous 2017. Provincial Directorate of Food and Agriculture of the Republic of Turkey Records

Arslan C,Tufan T. 2011. Determination of Herbage Yield, Nutrient Composition and Optimum Harvesting Date of Pastures in Kars District. Atatürk Üniversitesi Vet. Bil. Derg. 6(2): 131-138

Aydın A, Çaçan E, Başbağ M. 2014. Determination of The Botanical Composition of A Pasture in The Derik District of Mardin. Turkish Journal of Agricultural and Natural Sciences Special Issue(2): 1631-1637.

Babalık AA, Kılıç K. 2015. A comprehensive approach of Botanical Compositions and Forage Yields in a Rangeland. Research Journal of Biotechnology. 10.(10)
Babalık AA, Sarıkaya H. 2015. A research on the hay yield and botanical composition of the Zengi Rangeland in Isparta. Turkish Journal of Forestry (2): 96-101

Bakır Ö. 1987. Meadow-Pasture Management. Ankara University Faculty of Agriculture Publications. No: 992. pp. 362.

Bakoğlu A, Koç A. 2002. The Conıparison of Some Soil and Plant of Characteristic in Grazed and Protected Range Sites I. Comparison of Plant Cover Characteristic. Firat University Journal of Engineering Science. 14(1), 37-77.

Bakoğlu A, Baykal H, Çatal Mİ. 2019. A Research on The Botanical Composition of Handüzü Plateau. Turkish Journal of Agriculture - Food Science and Technology, 7(9): 13391343.

Balabanlı C, Albayrak S, Türk M, Yüksel O. 2006. Some Toxic Plants Growing In Rangelands Of Turkey And Their Effects On Animals. Suleyman Demirel University Journal of Foresty. Seri: A (2), 89-96.

Başbağ M, Sayar MS, Aydın A, Hosgören H, Demirel R. 2015. Some agronomical and quality traits in nine vetch (Vicia ssp.) species cultivated in Southeastern Anatolia, Turkey. Turkish Journal of Agricultural and Natural Sciences, 2(1): 69-77.

Beyiş ME, Sabancı CO. 2011. A Study on Botanical Composition and Hay Yield of Pastures in Gevaş District of Van. The Ninety Field Crops Congress of Turkey, Poster Papers. 12-15 September 2011. 2. Bursa/Turkey.

Bilgen M, Özyiğit Y. 2005. Determination of Vegetation Characteristics of Some Rangelands in Korkuteli and Elmalı. Mediterranean Agriculture Sciences. 18(2), 261-266

Buzuk G, Sabancı CO, Ertuş MM. 2009. A Study of Botanical Composition and Hay Yield of Pastures in Caldıran District of Van. The Eighty Field Crops Congress of Turkey. 19-22 October 2009, Hatay/Turkey.

Çaçan E, Aydın A, Başbağ M. 2014. Comparison of Botanical Compositions of Two Different "Protected and NonProtected" Natural Areas. Turkish Journal of Agricultural and Natural Sciences Special Issue: 2.

Çaçan E, Başbağ M. 2016. Exchange of the Botanical Composition and Hay Yield at Rangelands of Different Aspects and Altitudes of Bingol Yelesen-Dikme Villages. Journal of Agricultural Fakulty of Ege University. 53 (1):1-9

Çınar S, Hatipoğlu R, Avcı M, İnal İ, Yücel C, Avağ A. 2014. A Research on The Vegetation Structures of The Pastures in District Kırıkhan, Hatay. Journal of Agricultural Faculty of Gaziosmanpasa University. 31 (2): 52-60.

Çınar S, Hatipoğlu R, Avc1 M, İnal İ, Yücel C. 2018. A Research on The Determination of Botanical Composition of Pastures in District Tufanbeyli, Adana. Turkish Journal of Nature and Science.7(2) :21-29.

Çınar S, Hatipoğlu R, Avcı M, Yücel C, İnal İ. 2019. A Research on The Vegetation Structures of The Rangelands of District Tufanbeyli, Adana. KSU J. Agric Nat. 22(1):143-152.

Cinar S, Abdullayev A, Esenov N, Karadag Y. 2019. Determination of botanical composition, hay yield and forage quality of some natural rangelands in Kyrgyzstan's Chuy Region. Applied Ecology and Environmental Research. 18(1): 401-416.

Çiplak E. 2015. Determination of Botanical Composition and Yield Potential of Natural Pastures Vegetation in Gövelek Village of Van. Yuzuncu Yil University. Institute of Science. Master Thesis. pp. 46.

Çomaklı B, Öner T, Daşçı M. 2012. Changing of The Vegetation on Rangeland Sites with Different Using History Iğdır Univ. J. Inst. Sci. \& Tech. 2(2): 75-82.

Davis PH. 1978. Flora of Turkey and the east aegeon islands. Edinburgh Univ. Press, Edinburgh.

Ertuş MM, Pınar SM, Eroğlu H. 2018. A Study on Slightly Grazed Pasture in Onagıl Village of Çatak District in Van Province. International Congress on Agriculture and Animal Sciences. 7-9 November 2018. Alanya/Turkey. 
Ertuş MM, Pınar M. 2019. Determination of Pasture Status of Ordeklı Village Pasture in Hakkâri Province. Journal of Bartin Faculty of Forestry.21(2):543-549.https://doi: 10.24011/barofd.524227

Hammond K, Humphries D, Westbury D, Thompson A, Crompton L, Kirton P, Green C, Reynolds CK. 2014. The inclusion of forage mixtures in the diet of growing dairy heifers: Impacts on digestion, energy utilisation, and methane emissions. Agric. Ecosyst. Environ. 197, 88-95. https://doi.org/10.1016/j.agee.2014.07.016

Holechek JL, Pieper RD, Herbel CH. 2004. Range management: Principles and practicies. Prentice Hall, New Jersey 607 p.

Ispirli K, Alay F, Uzun F, Çankaya N. 2016. Impacts of Livestock Grazing and Topography on Vegetation Cover and Structure in Natural Rangelands. Turk J Agric Res. 3: 14-22. https://doi.org/10.19159/tutad.76350

Koç A, Gökkuş A, 1994. Determination of the Most Appropriate Stubble Height to be Left with Botanical Composition and Soil Covering Area of Güzelyurt Village Pasture Vegetation. Türk Tarım ve Ormancılık Dergisi, 18(6): 495-500.

Manga İ. 1975. The Place and Importance of Feed Lice Breeding in Eastern Anatolian Animal Husbandry). Journal Agricultural Faculty of Ataturk University. 6(3), 75-91.

Palta Ş, Genç Lermi A. 2018. Determination of Some Characteristics of Rangeland of Kutlubey Demirci Village in Bartın Province. Journal of Bartin Faculty of Forestry. 20(2): 352-359. https://doi.org/10.24011/barofd.437385

Reiné R, Ascaso J, Barrantes O. 2020. Nutritional Quality of Plant Species in Pyrenean Hay Meadows of High Diversity. Agronomy, 10,883. https://doi.org/10.3390/agronomy 10060883.

Sayar MS, Anlarsal AE, Basbag M. 2010. Current situation, problems and solutions for cultivation of forage crops in the Southeastern Anatolian Region. J. Agric. Fac. HR.U. 14: 59-67.

Sayar, MS, Han Y, Başbağ Y, Gül İ, Polat T. 2015. Rangeland Improvement and Management Studies in the Southeastern Anatolia Region of Turkey. Pak. J. Agri. Sci., Vol. 52(1): 9-18.

Serin Y, Tan M, Koç A, Zengin H. 2008. Türkiye'nin Çayır ve
Mera Bitkileri. Tarım ve Köyişleri Bakanlığı Tarımsal Üretim ve Geliştirme Genel Müd. Yayınları, Ankara.

Seydoşoğlu S, Saruhan V, Mermer A. 2015. Determination of the Botanical Composition of the Arid Pasture in District Eğil, Diyarbakır. Turk J Agric Res. (2015):2,76-82

Sturludóttir E, Brophy C, Belanger G, Gustavsson AM, Jørgensen M, Lunnan T, Helgadottir A. 2013. Benefits of mixing grasses and legumes for herbage yield and nutritive value in Northern Europe and Canada. Grass Forage Sci. 69: 229-240. https://doi.org/10.1111/gfs. 12037

Şahin B, Arslan S, Ünal S, Mutlu Z, Mermer A, Urla Ö, Ünal E, Özaydın KA, Avağ A, Yıldız H, Aydoğmuş O. 2015. Floristic Features of Rangelands of Çankırı Province. Journal of Field Crops Center Research Institute. 24(1):1-15.

Tallowin JRB, Jefferson RG. 1999. Hay production from lowland semi-natural grasslands: A review of implications for ruminant livestock systems. Grass Forage Sci. 1999, 54: 99 115.

Temel S, Şimşek U, Erdel E, Tohumcu F, Gökmen F. 2016. Effects of Different Soil Features on Floristic Composition of Ground Meadows. Journal of Field Crops Center Research Institute. 25 (Speccial Papers-2): 168-173

Terzioğlu, Ö, Yalvaç N. 2004. A Research on Determination of Grazing Starting Time Hay Yield and Botanical Composition of Natural Rangelands in Van Region (J. Agric. Sci.), 2004, 14(1): $23-26$

Topçu Demiroğlu G, Özkan ŞS. 2017. General View to MeadowRangelands and Forage Crops Cultivation of Aegean Region and Turkey. COMU J. Agric. Fac. 5 (1): 21-28

Turan N, Altuner F. 2014. The Roughage Production Potential, Problems and Suggestions in Van Province. Turk J Agric Res. 1(1). 91-97.

Ünal S, Mutlu Z, Mermer A, Urla Ö, Ünal E, Aydoğdu M, Dedeoğlu F, Özaydın KA, Avağ A, Aydoğmuş O, Şahin B, Aslan S. 2012. A Study on Assessment of Rangelands in Ankara Province. Journal of Field Crops Center Research Institute. 21(2): 41-49. 